\section{Far-red at End of Day and Reduced Irradiance Affect Plant Height of Easter and Asiatic Hybrid Lilies}

\author{
T.J. Blom ${ }^{1}$ \\ Ontario Ministry of Agriculture, Food and RuralAffairs, Horticultural Research \\ Institute of Ontario, Vineland Station, Ont. LOR 2E0, Canada
}

\author{
M.J. Tsujita ${ }^{2}$ and G.L. Roberts ${ }^{3}$ \\ Department of Horticulture, University of Guelph, Guelph, Ont. NIG 2W1, \\ Canada
}

Additional index words. Lilium longiflorum, photomorphogenesis, thermomorphogenesis, twilight

\begin{abstract}
Potted bulbs of Lilium longiflorum Thunb. 'Ace' and 'Nellie White' and Lilium (Asiatic hybrid) 'Enchantment' were grown in a greenhouse under ambient photoperiod (APP), 8-h photoperiod by removing twilight from ambient by blackout cloth (8PP), or 8PP extended with 1 hour of low-intensity far-red radiation (9PP). Height of 'Ace', 'Nellie White', and 'Enchantment' increased by $24 \%, 18 \%$, and $12 \%$, respectively, under APP and by $118 \%, 100 \%$, and $44 \%$, respectively, under 9PP compared to 8PP. In a second experiment, the effects of reduced irradiance $(0 \%, 25 \%, 50 \%$, and $75 \%$ shade) were determined on the same cultivars grown under APP or 8PP. The effects of APP on height were similar in magnitude for 'Ace' and 'Nellie White' but were insignificant for 'Enchantment' compared to 8PP. Shading increased height linearly for all cultivars. The regression was greater under APP $(2.8 \mathrm{~mm} /$ percent shade) than under $8 P P(1.8 \mathrm{~mm} /$ percent shade) for 'Ace' and 'Nellie White' combined. Plant height of 'Enchantment' was less affected by reduced irradiance. For all cultivars, APP or 9PP produced higher stem dry weight compared to 8PP. Shading decreased leaf and bulb dry weight of the Easter lily cultivars.
\end{abstract}

Several researchers (Erwin et al., 1987; Hendriks and Scharpf, 1985; Moe, 1990; Moe and Mortensen, 1992) have shown that a negative difference (-DIF) between day and night temperature reduces stem length of many plant species compared to a positive difference (+DIF). Growers of flowering potted plants are adapting this strategy to control plant height in lieu of applying plant growth regulators.

The precise effects of light intensity, photoperiod, and light quality on plant height during forcing are not understood well. Kohl and Nelson (1963) found that growth of Easter lilies was reduced by increased irradiance; Erwin et al. (1989) did not find a correlation, and Heins et al. (1982a) reported increased plant height with shading. In campanula ( $\mathrm{Cam}$ panula isophylla Moretti), -DIF had a greater effect under lower irradiance in January than in March (Moe, 1990).

Received for publication 2 Mar. 1995. Accepted for publication 13 Mar. 1995. We thank the Easter Lily Research Station, Brookings, Ore., for donating the Easter lily bulbs. The cost of publishing this paper was defrayed in part by the payment of page charges. Under postal regulations, this paper therefore must be hereby marked advertisement solely to indicate this fact.

${ }^{1}$ Research Scientist.

${ }^{2}$ Professor.

${ }^{3}$ Research Assistant.

HortScience, Vol. 30(5), August 1995 al., 1987; McMahon et al., 1991; Mortensen and Stromme, 1987; Proctor, 1973; Rajapakse et al., 1993; Roberts et al., 1994), using blackout curtains in greenhouses to achieve shorter photoperiods, if done early enough, may eliminate the effects of twilight (low R : FR). All previous photoperiodic studies on lilies were performed under conditions with lower night than day temperatures (+DIF). To our knowledge, the effects of daylength or daylight extension with various $\mathrm{R}$ : FR have not been reported with lilies grown under -DIF greenhouse conditions.

Our objectives were to determine the effects of 1) R : FR at the end of the day and 2) reduced irradiance under photoperiods with and without twilight using Easter and Asiatic lilies grown in greenhouses using-DIF. Physical limitations did not allow us to test the light treatments under +DIF conditions as well.

\section{Materials and Methods}

Photoperiod. On 15 Dec. 1993, commercially case-cooled bulbs of Easter lilies 'Ace' ( $18 / 20 \mathrm{~cm}$ in diameter) and 'Nellie White' (20/ $23 \mathrm{~cm})$ ] and the Asiatic hybrid 'Enchantment' $(10 / 13 \mathrm{~cm})$ were planted using one bulb per 15-cm-diameter, standard, 1.6-liter pot in Sunshine no. 4 mix (Sun Gro Horticulture, Bellevue, Wash.). Potted bulbs were placed in a greenhouse at the Horticultural Research Institute of Ontario (lat. $42^{\circ} \mathrm{N}$ ) at $17 \mathrm{C}$ until 6 Jan. 1994 when shoots extended $2 \mathrm{~cm}$ above the substrate. Plants subsequently were transferred to a $-4 \mathrm{C}$ DIF greenhouse (16C light/ $20 \mathrm{C}$ dark cycle) and grown until the first flower reached anthesis. Three photoperiodic treatments were used: 1) ambient (APP); 2) 8$\mathrm{h}$ photoperiod between 0815 and $1615 \mathrm{HR}$ (8PP); and 3) 8-h photoperiod followed by 1 -h FR radiation extension (9PP). The 8PP- and 9PP-treated plants were maintained in the same greenhouse, and the ambient-treated plants were grown in a separate greenhouse. Blackcloth was used for 8PP and 9PP and hand-pulled daily for closing at $1615 \mathrm{HR}$ and

Table 1. Influence of photoperiod (PP) on growth of 'Ace', 'Nellie White', and 'Enchantment' lilies forced under greenhouse conditions.

\begin{tabular}{|c|c|c|c|c|c|c|}
\hline \multirow[b]{2}{*}{$\mathrm{PP}^{z}$} & \multirow{2}{*}{$\begin{array}{c}\text { Plant } \\
\text { ht } \\
(\mathrm{cm})\end{array}$} & \multirow{2}{*}{$\begin{array}{l}\text { Stem } \\
\text { diam } \\
(\mathrm{mm}) \\
\end{array}$} & \multirow{2}{*}{$\begin{array}{c}\text { Leaf } \\
\text { surface } \\
\text { area } \\
\left(\mathrm{cm}^{2}\right)\end{array}$} & \multicolumn{3}{|c|}{ Dry wt $(\mathrm{g})$} \\
\hline & & & & Leaf & Stem & Bulb \\
\hline \multicolumn{7}{|c|}{ Ace } \\
\hline 9PP & $84.5 \mathrm{a}$ & $9.4 \mathrm{c}$ & 1210 & $4.6 \mathrm{~b}$ & $6.0 \mathrm{a}$ & $12.5 \mathrm{~b}$ \\
\hline APP & $48.3 \mathrm{~b}$ & $10.2 \mathrm{~b}$ & 1150 & $5.5 \mathrm{a}$ & $3.6 \mathrm{~b}$ & $15.8 \mathrm{a}$ \\
\hline $8 \mathrm{PP}$ & $38.8 \mathrm{c}$ & $10.8 \mathrm{a}$ & 1270 & $5.7 \mathrm{a}$ & $3.2 \mathrm{~b}$ & $12.6 \mathrm{~b}$ \\
\hline \multicolumn{7}{|c|}{ Nellie White } \\
\hline 9PP & $76.1 \mathrm{a}$ & $9.8 \mathrm{~b}$ & $1400 \mathrm{a}$ & 5.3 & $5.7 \mathrm{a}$ & $18.0 \mathrm{~b}$ \\
\hline APP & $44.8 \mathrm{~b}$ & $11.1 \mathrm{a}$ & $1360 \mathrm{ab}$ & 6.1 & $4.1 \mathrm{~b}$ & $21.5 \mathrm{a}$ \\
\hline $8 \mathrm{PP}$ & $38.0 \mathrm{c}$ & $11.0 \mathrm{a}$ & $1200 \mathrm{~b}$ & 5.5 & $3.0 \mathrm{c}$ & $22.9 \mathrm{a}$ \\
\hline \multicolumn{7}{|c|}{ Enchantment } \\
\hline 9PP & $75.1 \mathrm{a}$ & 6.1 & 631 & $2.0 \mathrm{~b}$ & $2.4 \mathrm{a}$ & 3.4 \\
\hline APP & $58.2 \mathrm{~b}$ & 6.3 & 695 & $2.5 \mathrm{a}$ & $2.2 \mathrm{ab}$ & 3.5 \\
\hline 8PP & $52.1 \mathrm{c}$ & 6.3 & 717 & $2.4 \mathrm{a}$ & $2.0 \mathrm{~b}$ & 3.8 \\
\hline
\end{tabular}

${ }^{2} 9 \mathrm{PP}=8$-h photoperiod between 0815 and 1615 HR followed by 1-h far-red radiation between 1615 and 1715 $\mathrm{HR}$; APP = ambient photoperiod; and 8PP = 8-h photoperiod between 0815 and $1615 \mathrm{HR}$. Each datum is an average of 24 plants measured at first-flower anthesis. Mean separation within column by Fisher's least significant difference at $P=0.05$. 
opening at $0815 \mathrm{HR}$. The 1 -h FR light extension used for the 9PP treatment was supplied under the black curtain by three $60-\mathrm{W}$ incandescent bulbs provided per $1.5 \times 12$-m bench space. Each light bulb was covered with a blue Lee filter no. 141 (Score Systems Inc., Ont., Canada). The R (630 to $700 \mathrm{~nm}$ ) : FR (700 to $750 \mathrm{~nm}$ ), as measured with a scanning spectroradiometer (model 1800; LI-COR, Lincoln, Neb.) was 0.029 (Watts per square meter per Watts per square meter) at an irradiance varying between $0.22 \mu \mathrm{mol} \cdot \mathrm{m}^{-2} \cdot \mathrm{s}^{-1}$ at bench level and $6.5 \mu \mathrm{mol} \cdot \mathrm{m}^{-2} \cdot \mathrm{s}^{-1}$ just below the light source. The R : FR measured for a typical day midway in the forcing cycle (1 Feb. 1994) under our ambient greenhouse conditions showed a decrease from 1.37 at (official) sunset, with irradiance at $3.8 \mu \mathrm{mol} \cdot \mathrm{m}^{-2} \cdot \mathrm{s}^{-1}$, to a $\mathrm{R}$ : FR ratio of 0.69 at $0.06 \mu \mathrm{mol} \cdot \mathrm{m}^{-2} \cdot \mathrm{s}^{-1} \approx 30 \mathrm{~min}$ after sunset. Heating setpoints in both greenhouses were $16 \mathrm{C}$ light/20C dark for a $-4 \mathrm{C}$ DIF. The temperature switch from dark to light and light to dark took place $1 \mathrm{~h}$ before the start of the light and dark period, respectively. This experiment was conducted twice at the same time.

Photoperiod and shading. In a second experiment, started on 4 Dec. 1992 and 15 Dec. 1993, newly emerged plants (21 Dec. 1993 and 6 Jan. 1994, respectively) of 'Ace' (1992, 20 to $23 \mathrm{~cm} ; 1993,18$ to $20 \mathrm{~cm}$ ), 'Nellie White' (1992 and 1993, 20 to $23 \mathrm{~cm}$ ), and 'Enchantment' (1992 and 1993, 10 to $13 \mathrm{~cm}$ ) were grown under ambient (APP) or 8-h photoperiod (8PP) greenhouses, maintained with similar-4C DIF conditions as previously described. The experiment was run twice. Within each greenhouse, plants were exposed further to one of four reduced light intensities: $0 \%$ (no shade), $25 \%, 50 \%$, or $75 \%$. Shading was provided by cloths consisting of various numbers of woven polyester and aluminum strips ( $\mathrm{AB}$ Ludvig Svensson, Kinna, Sweden) that were suspended permanently above the plants. The $\mathrm{R}$ : FR ratio of the light passing through the cloths did not differ from that of ambient light (data not shown).

Each experiment consisted of 12 plants per plot. Pots were spaced $25 \times 25 \mathrm{~cm}$. Plants were fertilized with a constant $200 \mathrm{mg} \mathrm{N} /$ liter using $20 \mathrm{~N}-2.2 \mathrm{P}-24.9 \mathrm{~K}$. Each week, from the beginning of photoperiod treatment until visible bud, plant height and number of unfolded leaves were recorded on six randomly selected plants per plot. At first-flower anthesis, the following data were collected on all plants per plot: plant height (from pot rim to the highest point of the pedicel of the first opening flower); number of aborted, primary, and secondary buds; total number of brown and green leaves; stem diameter (measured at $10 \mathrm{~cm}$ from the substrate and $10 \mathrm{~cm}$ from the top of stem); leaf surface area (model 3000; LI-COR); and dry weights of stem, leaves, and bulb (including roots).

Data were subjected to analysis of variance (SAS Institute, Cary, N.C.) and were followed by separation of means by least significant difference or regression analysis. Sampling and experimental errors were pooled if they were not significantly different.

\section{Results and Discussion}

Photoperiod. When compared with the 8PP treatment, the 1-h FR extension (9PP) increased plant height of 'Ace', 'Nellie White', and 'Enchantment' lilies by $118 \%, 100 \%$, and $44 \%$, respectively (Table 1). Corresponding height increases of these three cultivars were $24 \%, 18 \%$, and $12 \%$ under APP compared to $8 \mathrm{PP}$. These results suggest that height increases may have been caused by a sensitivity to radiation with a low $\mathrm{R}$ : FR (twilight) at the end of the day (Holmes and Smith, 1977), rather than due to increased photoperiod as shown in other lily studies comparing short days (SD) with natural days (ND) (Heins et al., $1982 b)$ or with ND vs. ND extended with incandescent radiation (Heins et al., 1982a; Kohl and Nelson, 1963; Post, 1941; Smith and Langhans, 1962; Weiler and Langhans, 1968; Wilkins et al., 1968). In growth chamber studies, exposing 'Enchantment' to 1-h FR radiation at the end-of-light period resulted in greater increases in plant height than at the end-ofdark period (Roberts et al., 1994). Moreover, there was no difference in plant height between plants grown under 8- and 10-h photoperiods while maintaining similar total visible

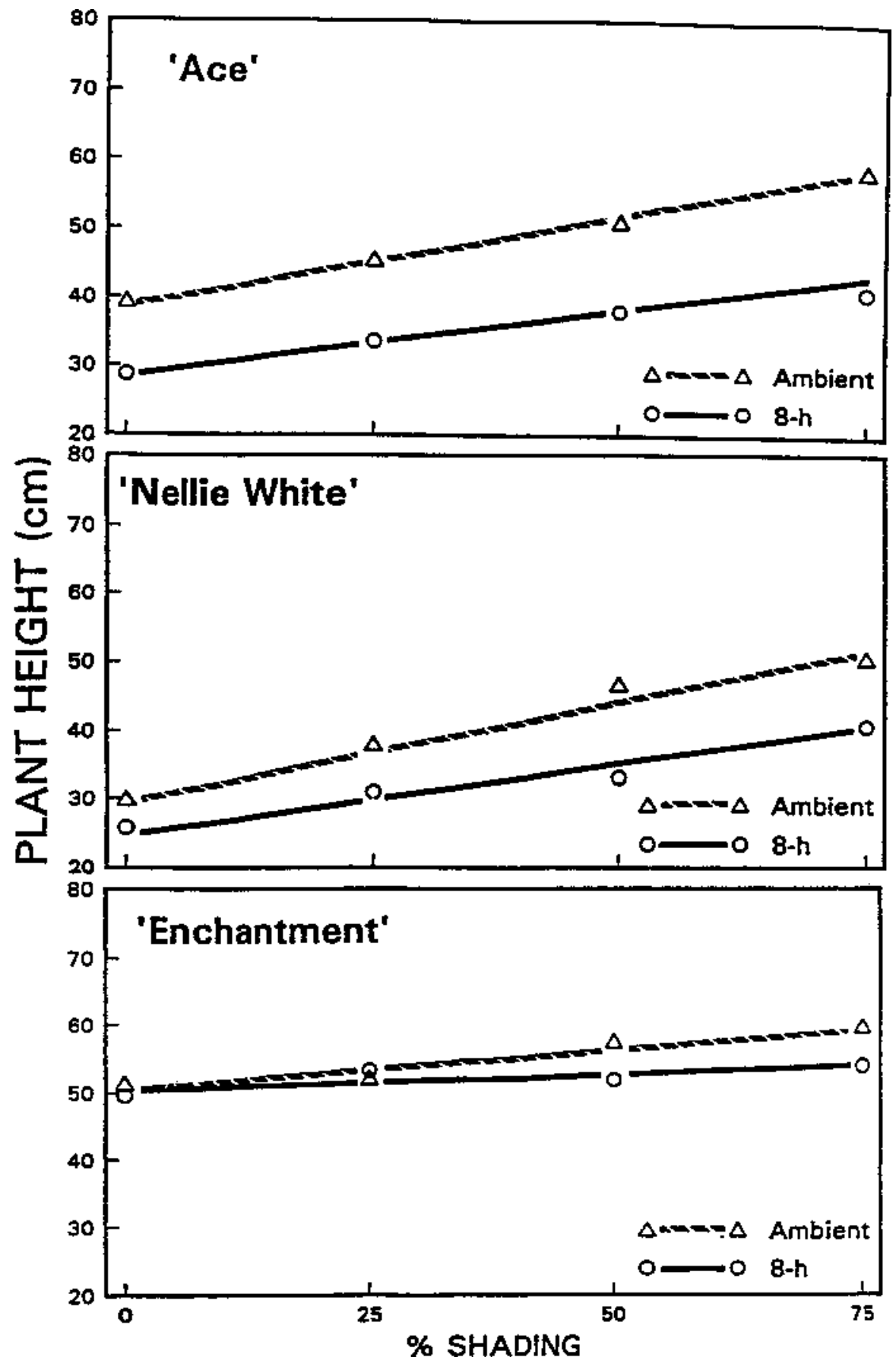

Fig. 1. Effects of shading on height of 'Ace', 'Nellie White', and 'Enchantment' lilies grown under 8-h (8PP) or ambient (APP) photoperiod. Data represents means of 24 plants. 'Ace': $\mathrm{Y}_{8 \mathrm{PP}}=29.0+0.18 \mathrm{X}, \mathrm{Y}_{\mathrm{APP}}$ $=38.7+0.27 \mathrm{X}, R^{2}=0.73$; 'Nellie White': $\mathrm{Y}_{8 \mathrm{PP}}=23.9+0.19 \mathrm{X}, \mathrm{Y}_{\mathrm{APP}}=28.2+0.30 \mathrm{X}, R^{2}=0.77$; 'Enchantment': $\mathrm{Y}_{8 \mathrm{PP}}=50.2+0.05 \mathrm{X}, \mathrm{Y}_{\mathrm{APP}}=50.2+0.13 \mathrm{X}, R^{2}=0.21$. 
radiation sums and light quality. This conclusion is supported by the fact that plants grown under APP (photoperiod varying between $9 \mathrm{~h}$ at emergence to $>13 \mathrm{~h}$ at flowering) were shorter than those under 9PP. Differences in light quality ( $\mathrm{R}$ : FR), light intensity, and its duration between 9PP and APP at the end-ofday period likely all are contributing to the differences in plant height between 9PP and APP.

Stem dry weight of all three cultivars and leaf surface area ('Nellie White' only) tended to parallel data for height (Table 1) due to photoperiod. Data for the other characteristics were reversed and significant with only two of the cultivars (stem diameter and bulb dry weight with 'Ace' and 'Nellie White' and leaf dry weight with 'Ace' and 'Enchantment'). Total plant dry weight was not affected by the photoperiod treatments (data not presented). Leaves of all three lily cultivars were visibly lighter green with the supplemental FR at the end-of-day period (9PP) compared to either 8PP or APP. These results are similar to those reported by Proctor (1973) and likely were caused by a decrease in chlorophyll a and $b$ (Holmes and Smith, 1977). Days to flower were not affected by photoperiod (data not shown).

Photoperiod and shading. Plant height of 'Ace', 'Nellie White', and 'Enchantment' increased with shading under APP and 8PP (Fig. 1 ). The response to shading was $50 \%$ greater under APP than under 8PP. The reason for this difference is unclear. Heins et al. (1982a) and Kohl and Nelson (1963) also showed that shading increased height under ambient conditions and +DIF. The Easter lily cultivars responded stronger to shading than 'Enchantment'. Without shading, similar to the results of the previous experiment, 'Ace' responded stronger to the elimination of twilight (APP vs. 8PP) than 'Nellie White' (Fig. 1; intercepts). This observation was most notable after the visible bud stage. 'Enchantment' was not affected by the twilight. Although the relative effect of shading on height was fairly consistent throughout the forcing season, the calculated internode length, as calculated by the weekly increase in plant height divided by the number of developed leaves, showed a negative correlation with accumulated irradiance of the previous week for the first year but not for the second year (data not shown). This inconsistency suggests that -DIF may not be effective under lower light conditions.

'Ace' and 'Enchantment' produced fewer flowering buds with increased shading, but this factor was not affected by photoperiod (data not shown), confirming earlier findings (Einert and Box, 1967; Weiler, 1978). The number of aborted buds per flower increased with shading on 'Enchantment' only (Table 2), as previously reported for Asiatic hybrids (Boontjes et al., 1975; Van Tuyl et al., 1985), but was not affected by photoperiod, as noted by Kamerbeek and Durieux (1971). In contrast, shading increased the leaf surface area but decreased the leaf dry weight of 'Ace' and 'Nellie White' but not of 'Enchantment'. This result suggests that 'Ace' and 'Nellie White'

Table 2. Effect of photoperiod (PP) and percent shading on growth of 'Ace', 'Nellie White', and 'Enchantment' lilies forced under greenhouse conditions.

\begin{tabular}{|c|c|c|c|c|c|c|c|}
\hline \multirow[b]{2}{*}{$\mathrm{PP}^{z}$} & \multirow{2}{*}{$\begin{array}{c}\text { Shade } \\
(\%)\end{array}$} & \multirow{2}{*}{$\begin{array}{c}\text { Aborted } \\
\text { buds } \\
\text { (no.) }\end{array}$} & \multirow{2}{*}{$\begin{array}{c}\text { Leaf } \\
\text { surface } \\
\text { area } \\
\left(\mathrm{cm}^{2}\right)\end{array}$} & \multirow{2}{*}{$\begin{array}{l}\text { Stem } \\
\text { diam } \\
(\mathrm{cm})\end{array}$} & \multicolumn{3}{|c|}{ Dry wt (g) } \\
\hline & & & & & Leaf & Stem & Bulb \\
\hline & & & Ace & & & & \\
\hline \multirow[t]{4}{*}{$8 \mathrm{PP}$} & 0 & 0 & 1060 & 11.7 & 5.6 & 2.8 & 22.8 \\
\hline & 25 & 0 & 1170 & 11.6 & 5.7 & 3.2 & 21.4 \\
\hline & 50 & 0 & 1240 & 10.9 & 5.6 & 3.3 & 19.3 \\
\hline & 75 & 0 & 1190 & 10.6 & 4.9 & 2.9 & 18.1 \\
\hline \multirow[t]{4}{*}{ APP } & 0 & 0 & 1210 & 11.9 & 6.7 & 4.4 & 21.1 \\
\hline & 25 & 0 & 1250 & 11.2 & 6.2 & 4.5 & 22.1 \\
\hline & 50 & 0 & 1340 & 11.0 & 5.8 & 4.8 & 19.6 \\
\hline & 75 & 0 & 1230 & 10.3 & 5.0 & 4.4 & 16.7 \\
\hline \multicolumn{8}{|l|}{ Significance } \\
\hline PP & & NS & $* *$ & NS & $* * *$ & $* * *$ & NS \\
\hline Shade & & NS & $\mathrm{L}^{*}$ & $\mathrm{~L}^{* * *}$ & $\mathrm{~L}^{* * *}$ & NS & $\mathrm{L}^{* * *}$ \\
\hline \multirow[t]{2}{*}{$\mathrm{PP} \times$ shade } & & NS & NS & NS & $*$ & NS & NS \\
\hline & & & Nellie White & & & & \\
\hline \multirow[t]{4}{*}{$8 \mathrm{PP}$} & 0 & 0 & 1060 & 13.4 & 5.2 & 2.2 & 23.9 \\
\hline & 25 & 0 & 1210 & 13.1 & 5.5 & 2.7 & 21.2 \\
\hline & 50 & 0 & 1210 & 12.0 & 5.1 & 2.6 & 22.8 \\
\hline & 75 & 0 & 1210 & 11.2 & 4.9 & 2.9 & 19.4 \\
\hline \multirow{4}{*}{ APP } & 0 & 0 & 1070 & 12.5 & 5.3 & 2.7 & 27.2 \\
\hline & 25 & 0 & 1230 & 11.5 & 5.5 & 3.4 & 24.1 \\
\hline & 50 & 0 & 1150 & 10.6 & 4.8 & 3.4 & 22.3 \\
\hline & 75 & 0 & 1240 & 10.6 & 4.8 & 3.6 & 19.4 \\
\hline \multicolumn{8}{|l|}{ Significance } \\
\hline PP & & NS & NS & $* * *$ & NS & $* *$ & * \\
\hline Shade & & NS & $\mathrm{L}^{*}$ & $\mathrm{~L}^{* * *}$ & $\mathrm{~L}^{*}$ & $\mathrm{~L}^{* * *}$ & $\mathrm{~L}^{* * *}$ \\
\hline \multirow[t]{2}{*}{$\mathrm{PP} \times$ shade } & & NS & NS & NS & NS & NS & NS \\
\hline & & & Enchantment & & & & \\
\hline \multirow[t]{4}{*}{ 8PP } & 0 & 0 & 635 & 5.9 & 2.2 & 1.9 & 3.9 \\
\hline & 25 & 0 & 714 & 5.9 & 2.3 & 1.8 & 3.1 \\
\hline & 50 & 0.2 & 551 & 5.5 & 1.9 & 1.6 & 3.2 \\
\hline & 75 & 2.3 & 680 & 5.8 & 2.3 & 1.8 & 3.8 \\
\hline \multirow[t]{4}{*}{ APP } & 0 & 0 & 583 & 5.7 & 2.5 & 2.2 & 4.3 \\
\hline & 25 & 0 & 559 & 6.1 & 2.2 & 2.1 & 4.6 \\
\hline & 50 & 0.5 & 663 & 5.7 & 2.3 & 1.9 & 3.2 \\
\hline & 75 & 1.5 & 553 & 5.5 & 1.8 & 1.7 & 4.9 \\
\hline \multicolumn{8}{|l|}{ Significance } \\
\hline PP & & NS & NS & NS & NS & $*$ & NS \\
\hline Shade & & $* * *$ & NS & $\mathrm{L}^{*}$ & $\mathrm{~L}^{*}$ & $\mathrm{~L}^{* *}$ & NS \\
\hline $\mathrm{PP} \times$ shade & & NS & NS & NS & NS & NS & NS \\
\hline
\end{tabular}

${ }^{28 P P}=8$-h photoperiod between 0815 and 1615 HR; APP = ambient photoperiod.

ns, ${ }^{*},{ }^{* *},{ }^{* * *}$ Nonsignificant or significant at $P<0.05,0.01$, or 0.001 , respectively. $\mathrm{L}=$ linear. Means are an average of data taken at first-flower anthesis from 18 plants.

adjust to lower light by expanding their leaf surface areas. With all cultivars, stem diameter decreased with shading (Table 2). Our data confirmed the results of Miller and Langhans (1989), who reported that shading reduced leaf and bulb (mother and daughter bulbs combined) dry weights of Easter lilies. Stem dry weight was the only characteristic that was affected by the photoperiod for all lily cultivars. The higher stem dry weight can be explained by the additional elongation under APP compared to 8-h PP. The effects of photoperiod were inconsistent for Easter lilies on features such as leaf surface area, stem diameter, and leaf and bulb dry weights.

Although our studies were not designed to determine if the effects of -DIF and light treatments were additive or interactive, the results clearly showed that end-of-day light quality (twilight) and irradiance levels (shading) affected plant height under-DIF growing conditions. Plant height of Easter lilies was reduced by $20 \%$ to $25 \%$ through eliminating twilight using blackout curtains compared to
APP. Reduced light intensity through shading increased plant height of lily cultivars at a rate of 0.5 to $3.0 \mathrm{~mm}$ per percent light reduction, a change that could not be explained by a change in light quality. The mechanism for these responses likely are not related. The Easter lily cultivars responded stronger to FR extension and light shading than the Asiatic hybrid 'Enchantment'. Long-day regimes, which may be given to partially vernalized bulbs, therefore, should not be provided by incandescent lamps (low R : FR ratio) at the end of the day but rather in the middle of the night. However, forced plants that appear to be too short at flowering can be given end-of-day incandescent lighting for additional height.

\section{Literature Cited}

Boontjes, J., A.J.B. Durieux, and G.A. Kamerbeek. 1975. Progress in the promotion of flowering in lilies by supplementary illumination. Acta Hort. $51: 261-263$

Downs, R.J., S.B. Hendricks, and H.A. Borthwick. 1957. Photoreversible control of elongation of 
pinto beans and other plants under normal conditions of growth. Bot. Gaz. 118:199-208.

Einert, A.E. and C.O. Box. 1967. Effect of light intensity on flower bud abortion and plant growth of Lilium longiflorum. J. Amer. Soc. Hort. Sci. 90:427-432.

Erwin, J.E., R.D. Heins, and M.G. Karlsson. 1989. Thermomorphogenesis in Lilium longiflorum. Amer. J. Bot. 76(1):47-52.

Erwin, J.E., R.D. Heins, M.G. Karlsson, R. Berghage, W. Carlson, and J. Biernbaum. 1987. The basics on Easter lilies: Light and temperature. GrowerTalks 51(7):84-86, 88, 90.

Heins, R.D., H.B. Pemberton, and H.F. Wilkins. 1982a. The influence of light on lily (Lilium longiflorum Thunb.). I. Influence of light intensity on plant development J. Amer. Soc. Hort. Sci. 107:330-335.

Heins, R.D., H.F. Wilkins, and W.E. Healy. 1982b. The influence of light on lily (Lilium longiflorum Thunb.). II. Influence of photoperiod and light stress on flower number, height, and growth rate. J. Amer. Soc. Hort. Sci. 107:335-338.

Hendriks, C.H.M. 1986. Dagverlenging bij lelies. Verkorting trekduur Oriental-hybriden mogelijk. Vakblad voor de Bloemisterij 51/52:106-107.

Hendriks, L. and H.C. Scharpf. 1985. Neues zur temperaturreaktion bei Chryanthemen. Deutscher Gartenbau 39(41):1914-1916.

Holmes, M.G. and H. Smith. 1977. The function of phytochrome in the natural environment-IV. Light quality and plant development. Phytochem. Photobiol. 25:551-557.
Kamerbeek, G.A. and A.J.B. Durieux. 1971. Influence of light on flower bud abscission in plants of the lily cultivar 'Enchantment'. Acta Hort. 23(I):71-74.

Kohl, H.C, Jr., and R.L. Nelson. 1963. Daylength and light intensity as independent factors in determining height of Easter lilies. Proc. Amer. Soc. Hort. Sci. 83:808-810.

McMahon, M.J., J.W. Kelly, D.R. Decoteau, R.E. Young, and R.K. Pollock. 1991. Growth of Dendranthema $\times$ grandiflorum (Ramat.) Kitamura under various spectral filters. J. Amer. Soc. Hort. Sci. 116:950-954.

Miller, W.B. and R.W. Langhans. 1989. Reduced irradiance affects dry weight partitioning in Easter lily. J. Amer. Soc. Hort. Sci. 114:306-309.

Moe, R. 1990. Effect of day and night temperature alterations and of plant growth regulators on stem elongation and flowering of the long-day plant Campanula isophylla 'Moretti'. Scientia Hort. 43:291-305.

Moe, R. and L.M. Mortensen. 1992. Thermomorphogenesis in pot plants. Acta Hort. 305:1925.

Mortensen, L.M. and E. Stromme. 1987. Effects of light quality on some greenhouse crops. Scientia Hort. 33:27-36.

Post, K. 1941. Problems in forcing Easter lilies. Proc. Amer. Soc. Hort. Sci. 39:415-418.

Proctor, J.T.A. 1973. Developmental changes in radish caused by brief end-of-day exposures to far-red radiation. Can. J. Bot. 51:1075-1077.

Rajapakse, N.C., M.J. McMahon, and J.W. Kelly.
1993. End of day far-red light reverses the height reduction of chrysanthemum induced by $\mathrm{CuSO}_{4}$ spectral filters. Scientia Hort. 53:249-259.

Roberts, G.L., M.J. Tsujita, and T.J. Blom. 1994. Far-red light reverses growth regulating action of negative DIF. HortScience 29:487. (Abstr.)

Roh, S.M. and H.F. Wilkins. 1977. Temperature and photoperiod effect on flower numbers in Lilium longiflorum Thunb. J. Amer. Soc. Hort. Sci. 102:235-242.

Smith, D.R. and R.W. Langhans. 1962. The influence of photoperiod on the growth and flowering of Easter lily (Lilium longiflorum Thunb. var. Croft). Proc. Amer. Soc. Hort. Sci. 80:599604.

Van Tuyl, J.M., J.E. Van Groenestijn, and S.J. Toxopeus. 1985. Low light intensity and flower bud abortion in Asiatic hybrid lilies. I. Genetic variation among cultivars and progenies of a diallel cross. Euphytica 34:83-92.

Weiler, T.C. 1978. Shade- and ancymidol-altered shape of potted Lilium longiflorum 'Ace'. HortScience 13:462-463.

Weiler, T.C. and R.W. Langhans. 1968. Effect of photoperiod on the vernalization requirement of Lilium longiflorum (Thunb.) 'Ace'. Proc. Amer. Soc. Hort. Sci. 93:630-634.

Wilkins, H.F., W.E. Waters, and R.E. Widmer. 1968. Influence of temperature and photoperiod on growth and flowering of Easter lilies (Lilium longiflorum Thunb. 'Georgia', 'Ace' and 'Nellie White'). Proc. Amer. Soc. Hort. Sci. 93:640649. 